\title{
PENGARUH HARGA, KUALITAS PRODUK, KUALITAS LAYANAN \& LOKASI TERHADAP KEPUTUSAN PEMBELIAN LAPIS KUKUS PAHLAWAN
}

\author{
Rahajeng Irna Sari ${ }^{1}$, Siti Istikhoroh ${ }^{2}$ \\ Universitas PGRI Adi Buana Surabaya ${ }^{1,2}$ \\ rahejengirnasari2008@gmail.com
}

\begin{abstract}
ABSTRAK
Dijelaskan riset menganalisa harga, kualitas produk, kualitas layanan serta lokasi terhadap keputusan pembelian lapis kukus pahlawan. Riset ini memakai pendekatakan kuantitatif deskriptif, telah diperoleh hasil thitung 2,564 serta Sig. sebesar, 012 sehingga, $012<, 05$. kualitas produk 2,055 sig. ,043<,05. kualitas layanan 2,216 serta Sig. ,036. lokasi 2,231 serta Sig. ,028. nilai f-hitung serta diketahui $F$ hitung 5,972 serta sig. ,000 $<0,05$. Disimpulkan pengujian secara terpisah serta bersamaan terbukti adanya pengaruh variabel bebas terhadap variabel terikat.
\end{abstract}

Kata kunci: Harga, kualitas produk, kualitas layanan \& Keputusan pembelian.

\begin{abstract}
Described the research analyzing the price, product quality, service quality and location of the decision to buy hero steamed layers. This research uses descriptive quantitative approach, has been obtained the results of tcount 2.564 and Sig. amounted to, 012 so that, $012<.05$. product quality 2,055 sig. , $043<$, 05. service quality 2,216 and Sig. , 036. location 2,231 and Sig. , 028. $f$ count value and known F-count 5.972 and sig. , $000<0.05$. It was concluded testing separately and together proved the influence of independent variables on the dependent variable.
\end{abstract}

Keyword: Price, product quality, service quality \& purchasing decisions. 


\section{PENDAHULUAN}

Perkembangan sektor usaha diberbagai bidang saat kini telah memasuki era digitalisasi serta kemajuan industri yang pesat, adapun perkembangan konsep strategi pemasaran yang semakin banyak. Semua sektor bisnis memiliki strategi tersendiri serta memiliki tingkat resiko yang berbeda satu dengan lainnya. Hal ini diperkuat atas adanya banyak bukti dilapangan mengenai sektor usaha disemua bidang. Tugas dari manajemen perusahaaan sebagai pemilik peran vital, yakni sebagai perencanaan strategi pemasaran harus didorong dengan ilmu manajemen yang berwawasan luas. Semakin luas ilmu manajemen akan menjadi pondasi awal dalam melakukan strategi bisnis.

Mengetahui semakin majunya teknologi saat ini sudah menyentuh ke semua sektor usaha, Dalam mengembangkan suatau bisnis perlu strategi serta pendalaman wawasan bagi manajemen atau pemilik usaha, hal ini menjelaskan menganai pentingnya persiapan matang sebelum berbisnis, menimimalisir resiko kerugian perlu dilakukan, sehingga hal yang dapat merusak berjalannya bisnis dapat ditekan sediikan rupa, perlunya manejemen yang handal serta profesinonal akan membawa prospek menuju berkembangnya serta majunya usaha. Usaha/bisnis harusnya teak terlepas dari kendali manajemen yang profesional, hal ini banyak ditemui pada organisasi atau perusahaan besar di Indonesia, kita melihat pentingnya manajemen berkualitas serta unggul untuk dijadikan pimpinan perusahaan. Semakin baik kualitas manajemen akan membawa dampak baik pula bagi kemajuan organisasi atau perusahaan tersebut.

Adapun faktor yang harus diperhatikan oleh pebisnis dalam mengembangkan usahanya yakni segi harga, konsumen sekarang sudah semakin pandai dalam menentukan pilihan produk yang akan dibelinya, pastinya konsumen akan membeli produk dengan harga terjangkau serta punya nilai lebih dari produk tersebut, tugas pebisnis yakni menjadikan usahanya bersahabat dengan konsumen. Adapun faktor penentu lainnya agar konsumen mau membeli produk kita yakni kualitas layanan yang kita beri ke konsumen, kualitas layanan sebagai ujung tombak strategi usaha harus benar-benar diberlakukan dengan sangat matang, sebab dalam proses mempengaruhi konsumen tidaklah gampang, diperlukan skill khusus yang dapat menarik minat konsumen serta loyal pada produk yang kita jual. Lokasi sebagai salah satu strategi berjualan juga harus ditentukan dengan sangat matang, lokasi harus dapat dinjangkau oleh konsumen serta mudah untuk diingat konsumen. Hal tersebut sebagai strategi jangka panjang perusahaan dalam memaksimalkan strategi bisnis yang efektif, apabila semua strategi dapat dijalankan dengan maksimal, maka selanjutnya hasil akan menjadi sangat maksimal. Pebisnis saat ini harus pintar membaca situasi serta melakukan peramalan usaha jangka panjang, seperti melakukan riset pasar.

Sesuai fenomena diatas disimpulkan rumusan masalah berikut:

1. Adakah pengaruh harga terhadap keputusan pembelian lapis kukus surabaya?

2. Adakah pengaruh kualitas produk terhadap keputusan pembelian lapis kukus surabaya?

3. Adakah pengaruh kualitas layanan terhadap keputusan pembelian lapis kukus surabaya?

4. Adakah pengaruh lokasi terhadap keputusan pembelian lapis kukus surabaya? 


\section{KERANGKA KONSEPTUAL}

Adapun kerangka konseptual riset ini yakni berikut :

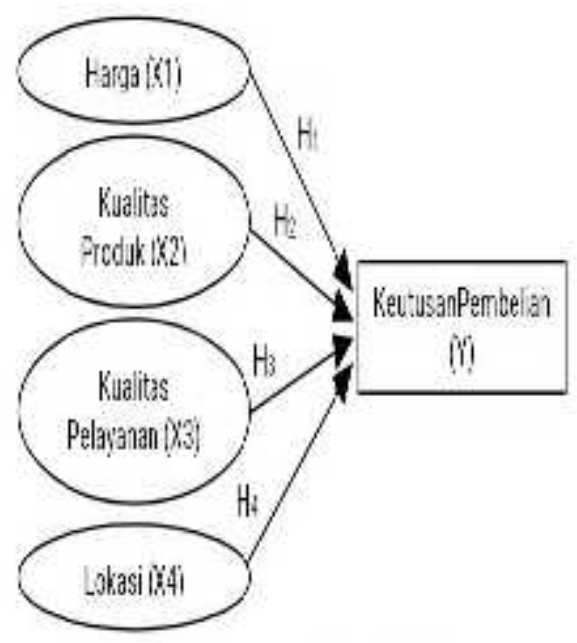

Gambar 1. Kerangka Konseptual

\section{METODE}

Dijelaskan riset ini memakai pendekatan kuantitatif deskriptif, populasi riset ini yakni konsumen yang membeli lapis kukus surabaya di otlet Jos Ghandos Krian,Sampel riset ini sejumlah 105 konsumen. Adapun teknik pengambilan sampel yakni insidental sampling.

\section{HASIL DAN PEMBAHASAN}

Tabel 1. Uji Validitas

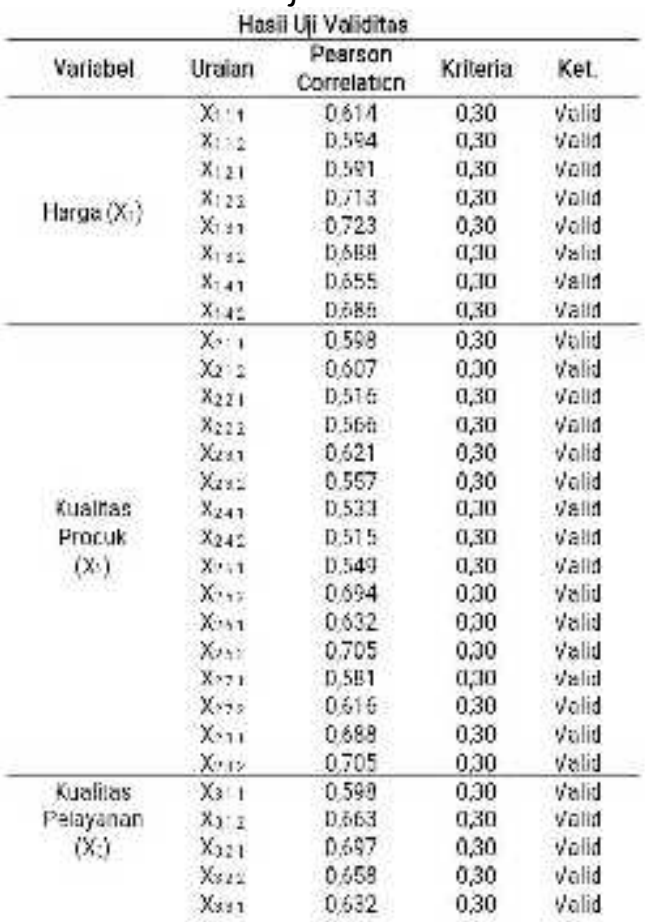




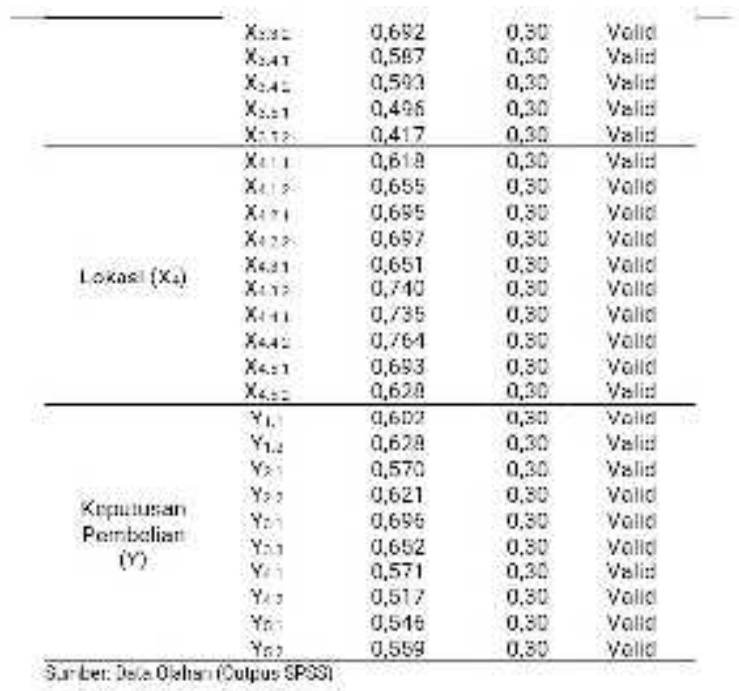

Dijelaskan validitas seluruh item mempunyai nilai correlation $>0,3$, yang berarti seluruh item pernyataan telah dianggap valid.

Tabel 2. Uji Reliabilitas

\begin{tabular}{lccc}
\multicolumn{4}{c}{ Hasil Uji Reliabilitas } \\
\hline \multicolumn{1}{c}{ Model } & $\begin{array}{c}\text { Cronbach's } \\
\text { Alpha }\end{array}$ & Kriteria & Ket. \\
\hline Harga $\left(X_{1}\right)$ & 0,813 & 0,70 & Reliabel \\
Kualitas Produk $\left(X_{2}\right)$ & 0,882 & 0,70 & Reliabel \\
Kualitas Pelayanan $\left(X_{3}\right)$ & 0,799 & 0,70 & Reliabel \\
Lokasi $\left(X_{2}\right)$ & 0,875 & 0,70 & Reliabel \\
Keputusan Pembelian (Y) & 0,799 & 0,70 & Reliabel \\
\hline Sumber Data Olahan (O) 1 tput SPSS) & &
\end{tabular}

Dijelaskan masing-masing variabel telah memenuhi syarat, karena nilai alpha cronbach $(>0,7)$. Jadi kuesioner atau instrumen yang digunakan dinyatakan reliabel.

Tabel 3. Hasil Uji Normalitas

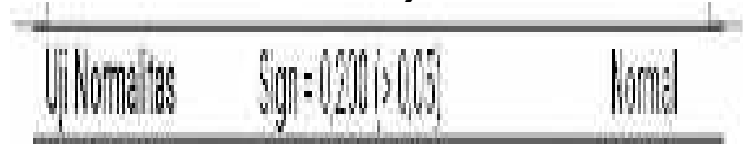

Dijelaskan nilai Sig. (2-tailed) $(, 94>, 05)$. Dapat disimpulkan pada hasil tes diatas nilai Asymp. Sig (2-tailed) memenuhi syarat sehingga data dikatakan berdistribusi normal. 
Tabel 4. Uji Multikolineritas

\begin{tabular}{|c|c|c|}
\hline \multicolumn{3}{|l|}{ Uji Muthikolinertas } \\
\hline Herga & $\begin{array}{l}\text { VF }=1,053 \mathrm{i}<10 \mathrm{i} \text { dan tolerance } \\
\text { setbesar }(0,950 \text { menderail }\end{array}$ & $\begin{array}{l}\text { Tiok Teriadi } \\
\text { Mutkolineritas }\end{array}$ \\
\hline Kualitas Prodtk & 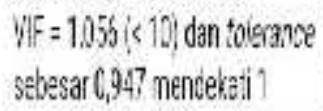 & $\begin{array}{l}\text { Tok Tenad } \\
\text { Mutcolineritas }\end{array}$ \\
\hline Kualitas Pelazarąan & $V F=1013 \mathrm{i}<10 \mathrm{i}$ dan toicance & Ticak Teriadi \\
\hline Lokasi & 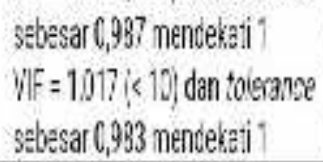 & $\begin{array}{l}\text { Mutkoiniaritas } \\
\text { Tiokk Tenaed } \\
\text { Mutzodinarilas }\end{array}$ \\
\hline
\end{tabular}

Dijelaskan uji multikolineritas diketahui nilai Tolerance $>, 10$ dan nilai VIF $<10$ maka dapat diartikan tidak ada kesamaan antar variabel bebas dalam penelitian ini.

Tabel 5. Uji Autokorelasi

$\begin{array}{ll}\text { UjiAutokorelasi } \quad D W=2,100 & \text { Tivak terjadi } \\ \text { Autckorelas }\end{array}$

Dijelaskan nilai dw sebsar 2,100, maka dapat disimpulkan data dalam penelitian ini tidak terjadi autokorelasi.

Uji Heteroskedastisitas

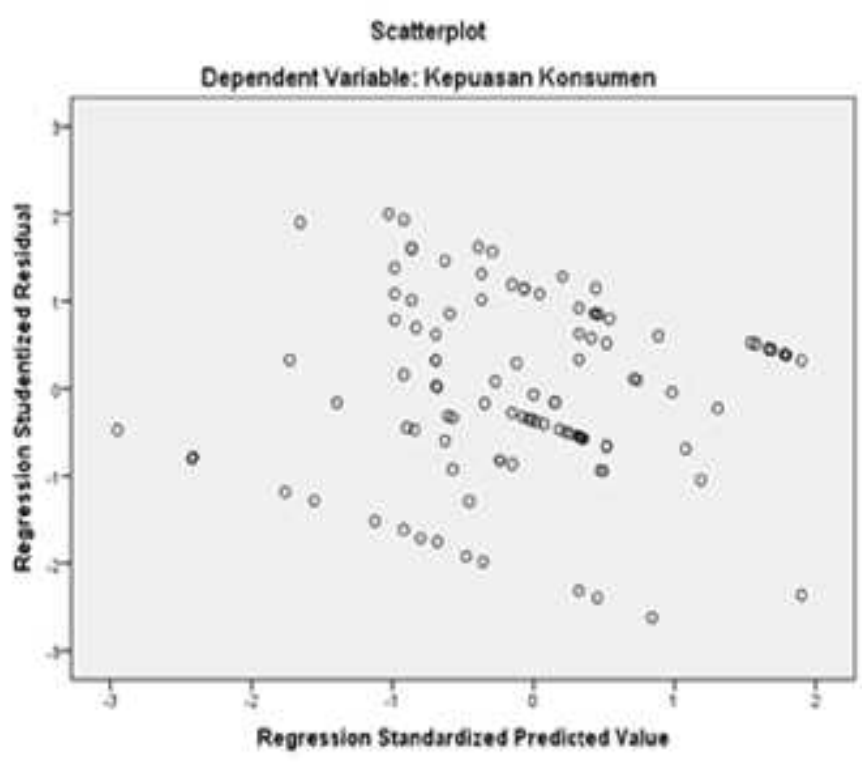

Gambar 1. Scatterplot

Dijelaskan gambar memperlihatkan titik-titik tersebar dengan acak serta tidak membentuk pola tertentu. 
Tabel 6. Analisis Regresi Linier Berganda

Hasil Analisa Regresi Linear Berganda

\begin{tabular}{|c|c|}
\hline Kaef sien Korelas: & $R=0,430$ \\
\hline Koefisien Determinasi & A Square $=0,193$ \\
\hline \multirow[t]{5}{*}{ Persamaan Garis regresi } & Constanta $=9,182$ \\
\hline & $X_{1}=0,244$ \\
\hline & $X_{2}-0,130$ \\
\hline & $X_{3}=0,219$ \\
\hline & $x_{4}=0,160$ \\
\hline
\end{tabular}

Dijelaskan persamaan regresi berikut:

$Y=, 439+.244 X_{1}+.130 X_{2}+210+, 160+e$

Dimana:

$Y=$ Keputusan pembelian

$X_{1}=$ Harga

$X_{2}=$ Kualitas produk

$X_{3}=$ Kualitas layanan

$\mathrm{X}_{4}=$ Lokasi

$a=$ Konstanta

Dijelaskan persamaan tersebut, maka dapat dijelaskan sebagai berikut:

a. konstanta (a) sebesar ,439

Memperlihatkan kosntanta sebesar, 439 .

b. koefisien variabel harga sebesar .244.

c. koefisien variabel kualitas produk sebesar ,130, Terbuksi bahwa setiap kenaikan atau penambahan satu satuan kualitas produk akan mengakibatkan meningkatnya keputusan pembelian ,130.

d. koefisien variabel kualitas layanan sebesar .210.

e. koefisien variabel lokasi sebesar .160.

Tabel 7. Uji-t

\begin{tabular}{|c|c|c|c|}
\hline \multicolumn{4}{|c|}{ Hasillujit } \\
\hline Variabel & $\ln$ ตุ & Sig. & (eteramgan \\
\hline Harga & $25 K^{2}$ & 0,012 & Sign fit.it \\
\hline Kuaitas Froduk & 2055 & $0,04 \%$ & Signfiliar \\
\hline Kua tas Felagenan & 2126 & 0,036 & Signflikar \\
\hline Lowasi & 221 & 0,028 & Sinffliar \\
\hline
\end{tabular}


Dijelaskan thitung harga 2,564 serta Sig. sebesar ,012 sehingga ,012<,05. Variabel kualitas produk thitung sebesar 2,055 sig. ,043<,05. Kualitras layanan 2,216 serta Sig. ,036, Lokasi 2,231 serta Sig. ,028. Dari hasil variabel tersebut maka dapat dinyatakan hipotesis diterima.

Tabel 8. Uji-f hipotesis

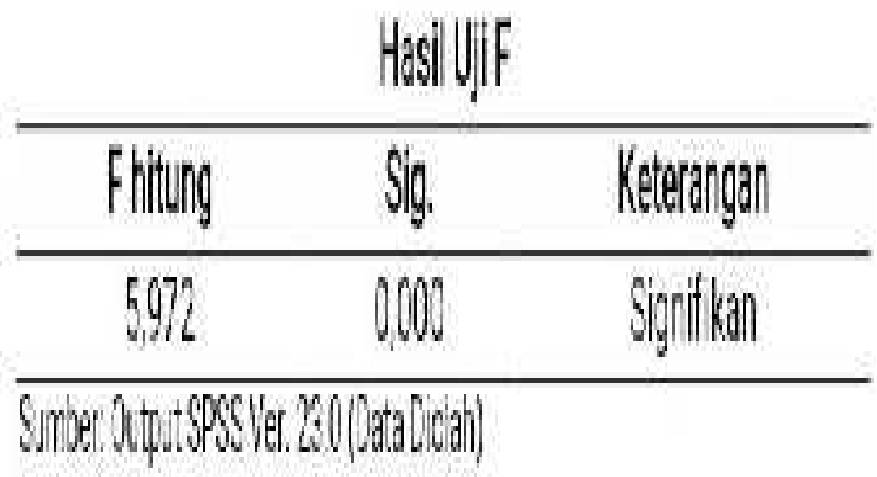

Dijelaskan diatas diperoleh nilai f-hitung serta diketahui $F$ hitung 5,972 serta sig. $, 000<0,05$,

\section{PEMBAHASAN}

Analisis uji-t harga thitung 2,564 serta Sig. sebesar ,012 sehingga ,012<,05. Dapat disimpulkan hipotesis diterima serta terbukti kebenarannya.

Analisis uji-t hipotesis kualitas produk thitung 2,055 sig. ,043<,05. Disimpulkan hipotesis diterima serta terbukti kebenarannya.

Analisis uji-t kualitas layanan diperoleh thitung 2,216 serta Sig. ,036. Disimpulkan hipotesis diterima dan terbukti kebenarannya.

Analisis uji-t lokasi didapatkan thitung 2,231 serta Sig. ,028. Disimpulkan hipotesis diterima serta terbukti kebenaranya.

\section{SIMPULAN}

Dijelaskan simpulan riset ini, analisis pengaruh harga terhadap keputusan pembelian terbukti positif serta signifikan berdasarkan hasil thitung. Sehingga dapat dinyatakan hipotesis 1 diterima.

Dijelaskan simpulan riset ini, analisis pengaruh kualitas produk terhadap keputusan pembelian terbukti positif serta signifikan berdasarkan hasil thitung. Sehingga dapat dinyatakan hipotesis 2 diterima.

Dijelaskan simpulan riset ini,kualitas layanan terhadap keputusan pembelian terbukti positif serta signifikan berdasarkan hasil thitung. Sehingga dapat dinyatakan hipotesis 3 diterima.

Dijelaskan simpulan riset ini semua variabel bebas terbukti adanya pengaruh terhadap keputusan pembelian terbukti positif serta signifikan berdasarkan hasil fhitung. Sehingga dapat dinyatakan hipotesis diterima. 


\section{IMPLIKASI}

Dijelaskan sesuai hasil riset ini telah menghasilkan suatu temuan terbaru bagi perusahaan, temuan ini diharapkan bisa menjadi bahan evaluasi yang dapat digunakan outlet Jos Gandhos untuk mengambil suatu kebijakan perusahaan waktu sekarang serta kemudian hari.

\section{KETERBATASAN PENELITIAN}

Dijelaskan adanya keterbatasan penulis saat melakukan penlitian yakni pada waktu yang sangat terbatas serta pendaan yang juga terbatas. Dengan temuan ini penulis berharap temuannya dapat dijadikan pedoman bagi Outlet Jos Gandhos serta untuk dijadikan bahan pembanding pada riset terbaru. 


\section{DAFTAR RUJUKAN}

Alma, Buchari. 2014. Manajemen Pemasaran Dan Pemasaran Jasa. Bandung: Alfabeta.

Alma, Buchari. 2016. Manajemen Pemasaran Dan Pemasaran Jasa. Bandung: Alfabeta.

Boyd, Harper W. 2000. Manajemen Pemasaran (Edisi Kedua). Jakarta: Erlangga.

Ghanimata, Fifyanita. 2012. "ANALISIS PENGARUH HARGA, KUALITAS PRODUK, DAN LOKASI TERHADAP KEPUTUSAN PEMBELIAN."

Kotler, Philip, and Gary Amstrong. 2008. PRINSIP - PRINSIP PEMASARAN EDISI 12 JILID 2.

Rachman, Mohammad Munir. 2019. METODOLOGI PENELITIAN. Surabaya: Aplikasi Komputer Statistik. 